Fireworks Night is an annual British event that marks the occasion of the foiling of the Gunpowder Plot on the $5^{\text {th }}$ November 1605. These nocturnal festivities recount the arrest of Guy Fawkes, whilst he was guarding the explosives secretly placed beneath the House of Lords. Airwaves reports the gunpowder, treason and plot found in this month's Thorax..

\section{EXPECTING THE UNEXPECTED...}

Guys Fawkes would never have expected to be arrested for his part in the Gunpowder Plot. Indeed, predicting this unplanned event would have been far from the plotter's thoughts. However, Nazir Lone and colleagues (see page 1046). have done exactly that and focused on predicting unplanned events, in this case predicting the risk of unplanned hospital readmission in survivors of critical illness. By population based analysis, and using the Scottish linking registry data for patients discharged from ICU, the authors observed that not only were unplanned 90day hospital readmissions common following ICU survival, but pre-existing illness better predicted readmission than acute illness. Understanding modifiable risk factors could improve outcome, although this is all a little late for Guys Fawkes and his colleagues who did not plan for the unexpected.

\section{THE LONG GAME...}

The Gunpowder Plotters rented a groundfloor cellar that lay directly beneath the House of Lords, and over a long time, from March to the November, 36 barrels of gunpowder were moved into position. Unlike the plotters, Greet Hermans and colleagues (see page 1037) considered both the long game and the short game in their study investigating the mortality and morbidity impact of a long vs a short ICU stay. This 5 year follow-up study of the EPaNIC trial demonstrated that a longer length of ICU stay ( $\geq 8$ days), compared with a shorter length of ICU stay ( $<8$ days), was associated with a greater mortality and morbidity. Risk factors included use of corticosteroids, neuromuscular blocking agents, benzodiazepines with long stay patients having lower $6 \mathrm{MWD}$. Playing the long game was unhelpful for the Gunpowder Plotters and must be avoided in all ICU patients.

\section{DON'T YOU REMEMBER, THE FIFTH OF NOVEMBER...}

The Gunpowder Plot was revealed to King James I in an anonymous letter that had been sent to Lord Monteagle on $26^{\text {th }}$ October
1605. This led to Parliament being searched on the 4th November with Guy Fawkes, and the explosives, being found in the basement. For his service in protecting the crown, Lord Monteagle was rewarded with a dowry of around $£ 700$ per year. An economic approach was employed by Chloe Bloom and colleagues (see page 1078) in their study investigating the impact on health outcome of switching inhalers to cheaper equivalent products. Using UK primary care records, they identified a cohort of 569901 asthma and 171,231 COPD regular inhaler users. Interestingly, inhaler switches from brand-to-generic were associated with reduced exacerbation frequency and switching patients to the cheapest equivalent inhaler would have been expected to save around $£ 6$ million per annum. That is close to the $£ 4$ million a year that Lord Monteagle would have received for foiling the Gunpowder plot today.

\section{GUNPOWDER}

Gunpowder consists of mixture of sulphur and charcoal (the fuel) combined with potassium nitrate (the oxidising agent). When ignition occurs in a confined space (such as a gun barrel) there is sufficient force to propel the bullet, without rupturing the weapon. However, if one were to burn a pile of gunpowder exposed to air it burns (rather than explodes), producing thick black smoke. In this month's Thorax (see page 1070), Rylance and colleagues look at the effect of black smoke - much of it from cooking stoves - on Malawian children. Two thirds of the 804 children in the study had carboxyhaemoglobin levels greater than WHO recommendations. Median carboxyhaemoglobin was lower and forced vital capacity (FVC) higher in those children whose households had a cleaner-burning biomass-fuelled cookstove. The authors conclude that further research is needed into clean-air interventions to maximise healthy lung development in children. Gunpowder was first developed by the Taoists, for medicinal purposes, in 904 AD. Any medicinal benefit to the lungs seems unlikely...

\section{TREASON}

As the triumvirate write this piece, former British Prime Minister David Cameron has been accused of treason for suggesting the British monarch "purred" on the phone when Scotland chose to remain part of the United Kingdom. In the study by Rodriguez et al (see page 1020), in this month's journal, the subject matter is wheezing rather than purring. The specific focus of this systematic review is the associations between urbanisation and asthma prevalence in low and middle income countries. The authors found that living in a city is consistently associated with a higher prevalence of asthma, regardless of the definition used. The authors suggest that future studies should explore what risk factors, associated with city living, might be harmful. The urban environment of London in the $17^{\text {th }}$ century was particularly harmful for gunpowder plotters Catesby and Percy (whose heads were placed on spikes) and four co-conspirators (who were hung, drawn and quartered). Let's hope a similar fate does not await former prime ministers whose memoires are rather too candid!

\section{AND PLOT}

In the patient described by Svenningsen and colleagues (see page 1087) one might plot the asthma control questionnaire result or sputum eosinophil count against time (before and after dupilumab). If one did so, the plot would show a marked improvement, following treatment. However, it is the image and not the plot which demonstrates the response to treatment most dramatically.

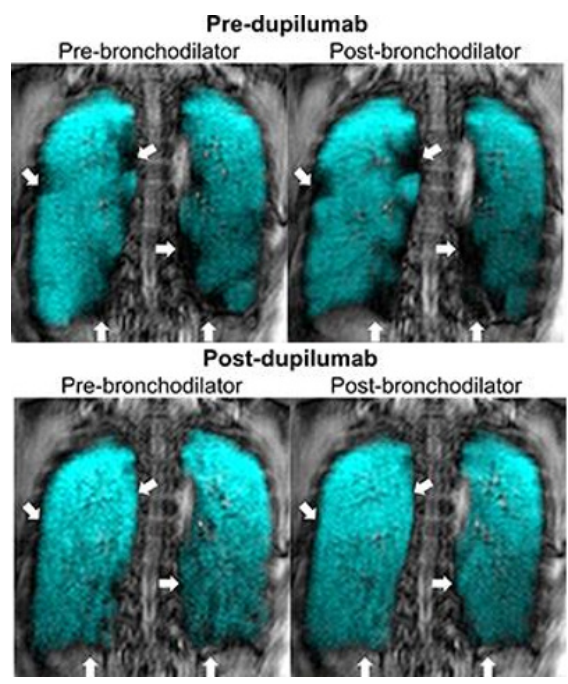

Funding The authors have not declared a specific grant for this research from any funding agency in the public, commercial or not-for-profit sectors.

Competing interests None declared.

Patient consent for publication Not required.

Provenance and peer review Commissioned; internally peer reviewed.

(C) Author(s) (or their employer(s)) 2019. No commercial re-use. See rights and permissions. Published by BMJ. 